\title{
BERTOLT BRECHT Y LAS MISERIAS DEL TERCER REICH
}

\section{BERTOLT BRECHT AND THE MISERIES OF THE THIRD REICH}

\author{
Alba Baro Vaquero \\ Universidad Autónoma de Madrid
}

\section{ABSTRACT}

This paper proposes an analysis of the Bertolt Brecht's play Fear and Misery of the Third Reich. Although it has been usually considered as one of the less brechtian plays a long his work, more attached to the conventions of traditional drama, our reading will try to emphasize all its topics coming from epic theatre, those which are characteristics of brechtian method and his particular way of seeing art and reality. In this way, we will be exploring how the playwright confronts such a difficult period, marked by the Nazi power and the obligatory exile. As a result, we will maintain that the play can be understood as a statement, adapted to its particular context, of Brecht's strong aim to make an art committed with true.

Key words: Brecht, theatre, Nazism, true.

\section{RESUMEN}

El artículo propone un análisis de la obra de Bertolt Brecht Terrory Miseria del Tercer Reich. Si esta ha sido considerada normalmente una de sus obras menos brechtianas, más apegadas a la dramática tradicional, en nuestra lectura trataremos de enfatizar todos sus elementos 
representativos del teatro épico, derivados del método brechtiano y característicos de su peculiar concepción del arte y la realidad. De este modo iremos profundizando en cómo el dramaturgo afronta en su teatro una época tan difícil como la del dominio nazi y el obligado exilio. Como resultado, veremos que esta obra puede considerarse una afirmación, adaptada a su particular contexto, del firme propósito de Brecht de hacer un arte comprometido con la verdad.

Palabras clave: Brecht, teatro, nazismo, verdad.

Fecha de recepción 25 de febrero de 2019.

Fecha de aceptación: 8 de abril de 2019.

Cómo citar: Baro Vaquero, Alba (2019), «Bertolt Brecht y las miserias del Tercer Reich», en Actio Nova: Revista de Teoría de la Literatura y Literatura Comparada, 3: 1-25.

DOI: https://doi.org/10.15366/actionova2019.3.001 


\section{INTRODUCCIÓN}

Terror y miseria del Tercer Reich ha sido señalada como una de las obras de Brecht menos transgresoras respecto a los principios de la dramaturgia tradicional. Si bien, como trataremos de exponer a lo largo de este artículo es posible encontrar en ella gran parte de los rasgos característicos del teatro épico brechtiano. Aunque sea cierto que el autor parece dispuesto a practicar una dramaturgia más convencional o a dejar cierto espacio a la identificación con la escena, estas particularidades, lejos de resultar de un relajamiento o un abandono parcial de su método, habrían de entenderse como el resultado de su aplicación fiel y consecuente.

Recordemos brevemente que la «revolución teatral» de Brecht consistía en la ruptura con la dramática tradicional o aristotélica, es decir, aquella basada en la identificación del espectador con los personajes (gracias a la imitación que de estos realizan los actores). En contraposición, propone un nuevo principio de construcción dramática: el distanciamiento. Esto es, que la acción del personaje se representara como «extraña», como «un fenómeno social que no es natural», de tal forma que lo que sucede deje de resultar obvio y familiar para provocar asombro, curiosidad y la adopción de una postura crítica (Brecht, 2004). Desde su postura marxista, Brecht, apuesta por el realismo, el cual no se limita al contenido de la representación: el teatro mismo había de mostrarse como teatro, el engaño o ilusión debía ser parcial, «de modo que siempre pueda ser reconocida como ilusión» (2004). Frente al realismo de Luckács defiende la variación e innovación en el plano formal. Por un lado, porque, para Brecht, el realismo de una obra «solo puede ser juzgado según se adapte a la realidad en cada caso concreto», y la realidad es algo transformable y cambiante, determinado social e históricamente. Por otro lado, porque el objetivo del arte no solo había de ser interpretar aquella adecuadamente: «ha de producir la realidad y al propio tiempo influirla, contribuir, en la misma praxis artística, a su transformación» (Brecht 1973: 249).

El realismo brechtiano exige, en consecuencia, evaluar cada situación específica para modificar los juicios (y la práctica artística) a medida que esta es arrastrada por el cambio (Jameson 2009: 173). Solo en ese sentido es posible hablar de un «método» en Brecht: comprendiendo que, en tanto que "práctica/teórica», no es algo traducible a reglas o postulados inamovibles, pues lo que busca ante todo es enfrentarse a cada situación concreta 
y coyuntura histórica particular para construirse de forma distinta (Rodríguez, 1998: 162). De acuerdo con esto, como dice Ray (2012), la verdad política contenida en una obra únicamente puede ser evaluada en base a un riguroso análisis de su contexto y sus efectos.

En consecuencia, solo prestando atención a los orígenes y al momento histórico y social en que fue producida la obra es posible encarar, ya no solo un análisis crítico, sino coherente con los mismos preceptos que el dramaturgo alemán imponía a su escritura. El teatro de Brecht ha de entenderse siempre como una intervención específica en una situación particular (Ray 2012). Más aun, tal vez, en un texto como este, escrito en 1938, perteneciente al ciclo de obras anti-nazis y a un periodo, por tanto, en que los eventos que estaban teniendo lugar demandaban un urgente esfuerzo por ser comprendidos y una renovación de la forma dramática adecuada. Más en concreto, Terror y miseria del Tercer Reich corresponde al contexto de emigración alemana, siendo escrita para ser representada, como nos cuenta Benjamin, ante un público que llevaba cinco años de exilio (1996: 31).

Las obras de Brecht, en definitiva, sólo pueden comprenderse como parte y resultado de la historia del siglo Xx, pero también lo son de su propia historia (no de su yo genial o íntimo, ideas en las que él no creía, sino de las situaciones que, dentro de aquella historia, le tocó vivir). De manera que la cuestión de la emigración está lejos de ser algo tangencial. Podría considerarse incluso que todas las teorías del teatro épico y el distanciamiento no suponen en el fondo más que una teoría del exilio, resultado de una determinación por «seguir luchando contra quienes le han exiliado aunque el regreso sea imposible» (Rodríguez 1998: 101).

Nada de lo dicho implica que hoy la obra de Brecht haya perdido su vigencia, al contrario, su específica ubicación histórica puede convertirse en su valor más alto. Así parecía entenderlo ya Benjamin en el momento de su aparición: «Tal vez solo a ese drama le esté dado albergar en sí la incandescente actualidad de tal manera que llegue a la posteridad como un acerado testimonio» (1996: 33). También su propio autor apuntaba que Terrory miseria del Tercer Reich «quizá no será una denuncia después del hundimiento de ese 'imperio', aunque quizá sí una advertencia» (1969: 97).

Antes de pasar al análisis de las tramas, el contenido y los elementos clave de las piezas que componen la obra, comentaremos brevemente, desde una perspectiva general, sus aspectos formales, atendiendo siempre a su incardinación dentro del proyecto teatral brechtiano. 
La misma forma de la obra, con su división en pequeñas piezas (hasta veintisiete), permite hacer una selección que facilitaría su puesta en escena en las condiciones precarias de la época, a la vez que consigue darle al conjunto el carácter episódico y fragmentario que buscaba el teatro épico. De este modo la acción avanza «a empujones como las imágenes del celuloide» (Benjamin 1996: 12), permitiendo enfrentar una situación con otra para que el público pueda tomar una posición crítica.

Las piezas siguen una progresión temporal que va de 1933 a 1938. Conforman, así, una especie de crónica de los cinco años del Tercer Reich, de tal forma que, aun representando el presente, Brecht logra poner en práctica su idea de «historización» (Brecht 2004: 137): los sucesos definitorios del Tercer Reich aparecen en cierto modo como procesos históricos, donde, a diferencia de lo que ocurre en los libros de historia y los grandes documentos de la cultura, los protagonistas no son los héroes con sus batallas o triunfos sino los derrotados y explotados en su existencia concreta y sus vidas cotidianas. La historización es sobre todo una de las formas de distanciar ${ }^{1}$, que nos permite comprender el carácter circunstancial y, al fin, pasajero, no por ello irrelevante, de lo representado. Se trata, como diría Benjamin, de llevar «al pasado a colocar al presente en su situación crítica» (2008: 473).

La división en piezas también permite cumplir con el propósito brechtiano de romper con la unidad y linealidad temporal propia de la tragedia, ubicando la tensión en los acontecimientos particulares en lugar de hacia el desenlace (Benjamin 1996: 8). En lo que respecta a cada una de las piezas el tiempo aparece tramado de diversas formas. Algunas, cuyo desenvolvimiento es más cercano a la parábola, trazan el rodeo propio del teatro épico (Brecht 1948). Mientras que otras, mucho más largas y complejas, que incluso incluyen otras historias dentro de su propia historia, toman ellas mismas un carácter episódico. Este último es el caso de la pieza que tomaremos como referencia principal en nuestro análisis: la tercera, «La cruz de tiza».

Por último, ciertamente podría alegarse que es difícil que no se de cierta proyección sentimental o identificación con determinados personajes (como la mujer judía o el obrero), aunque en ningún caso encontremos entre ellos héroes ni grandes figuras. Pero tal vez sería simplificar el pensamiento teatral de Brecht el pretender que ello rompe con el efecto de distanciamiento. Para empezar, como hemos señalado al comienzo, rechazaba la idea del arte

\footnotetext{
${ }^{1}$ De hecho Brecht llega a definir el distanciamiento en general como una forma de historizar: «distanciar significa colocar en un contexto histórico» (2004: 84).
} 
como algo atemporal y adherido a unos principios inviolables, lo cual incluye a sus propias ideas artísticas. De tal modo que no tiene problema en señalar que la identificación puede ser útil en determinadas ocasiones. En cualquier caso, la dramática no aristotélica no pretendía renunciar a las emociones del público, sino poner el «aspecto emocional en consonancia con su aspecto crítico» (Brecht 2004: 25). Por último, hay que recordar la vocación práctica del teatro brechtiano, que pretendía sacar a los espectadores de su papel pasivo, convirtiéndoles en ocasiones, directamente en actores «profanos». Y para dicho trabajo actoral la obra ofrece grandes posibilidades de experimentación y reflexión en torno al distanciamiento: si el actor en el exilio representa a un general nazi, incapaz de identificarse afectivamente con él, tendrá que buscar otras formas de trabajar su personaje (Benjamin 1996: 13).

Brecht pone el foco en las situaciones antes que en los personajes. La obra podría considerarse como un drama social donde la verdadera protagonista es, más bien, la sociedad alemana de la época del Tercer Reich, por cuyos diferentes escenarios van recorriendo las diversas escenas: de las fábricas a las cárceles pasando por cocinas y salones, de los juzgados a los campos de concentración pasando por los hospitales y laboratorios. En todos ha penetrado el terror y la miseria: hay gentes terroríficas y aterradas, miseria material y moral. Hasta el punto (y ahí está lo verdaderamente catastrófico) de convertirse en algo habitual, enraizado en el día a día y en el mismo carácter de las personas. Ese es justamente el objeto sobre el cual el distanciamiento busca actuar: aquello que se nos ha hecho normal y natural bajo el sistema dominante, allí donde este ha llegado a penetrar en nuestros gestos y nuestras palabras, para intentar volverlo extraño, descubriéndonos que tras esos sucesos superficiales hay causas más profundas que nos pasan desapercibidas. En nuestro análisis intentaremos rescatar dichos «gestos de la pobreza, la ignorancia, la impotencia» (Benjamin 1996: 17) que a lo largo de la obra aparecen recurrentemente citados.

La tesis decisiva que atraviesa todas las piezas la resume Benjamin con una frase de El Proceso de Kafka: «la mentira se convierte en el orden universal» (1996: 32). Compartiendo esta interpretación, trataremos, por un lado, de ir más allá para reflexionar sobre las consecuencias de tal predominio de la mentira y, por otro, de dar la vuelta a esta perspectiva: poniendo el foco, no ya en el orden de la mentira, sino en el desorden que genera la ocultación, tergiversación e ignorancia de la verdad. Pues fue la lucha por la verdad la tarea última que Brecht se propuso para su teatro. 


\section{Contradicción.}

Ya hemos hablado de cómo el teatro épico se proponía quebrar el carácter total y heterogéneo de la escena. Si bien, es necesario insistir en que con ello no pretendía abandonarla a la pura disgregación. Las rupturas, separaciones, multiplicidades... interaccionan en una constante tensión dialéctica (dialéctica que nunca llega a cerrarse del todo). De lo que se trata es de conseguir mostrar la contradicción bajo la aparente unidad de las cosas (Brecht 1969: 81). Y así lo hace Brecht con la realidad social alemana ya desde los primeros versos, donde nos habla de «El gran desfile alemán». El conjunto de las personas subsumidas bajo la aparente unidad de la palabra «pueblo», de la que se habían apropiado los discursos fascistas, pronto se nos revela heterogéneo y desordenado: se desmembra entre la palidez del rostro asustado de obreros, ancianos o niños y el rojo sangre de las banderas. La pregunta es lanzada de manera directa: «qué pueblo, compuesto de qué gentes / en qué estado y con qué principios» (1989b: 2).

Los versos que encabezan la primera pieza, «Comunidad Nacional», continúan explotando las mismas antítesis: el pueblo poderoso para los fascistas no es sino un «pueblo de hombres quietos». Las contradicciones seguirán desarrollándose en cada una de las escenas, aunque ya no como formulaciones generales y abstractas, sino encarnadas en lo más concreto y cotidiano, en los personajes, las tramas, las palabras y las acciones. Y de manera particular a través del empleo del gestus, elemento clave del teatro épico, basado en el distanciamiento del actor con respecto al «gesto social», esto es, respecto a las acciones y palabras de su personaje, poniendo en evidencia hasta qué punto estos llevan inscritas las condiciones de las que parten (Eagleton, 2007).

Los protagonistas de la primera pieza son dos SS desorientados que tras la marcha de las antorchas del 1933 se adentran en unas barracas donde aun no han llegado las banderas rojo sangre marcadas con la cruz que engalanan ya gran parte de las calles alemanas. El juego de contradicciones se despliega aquí más en concreto a través del Grundgestus. Como explica Jameson (2009) si el gestus subsume un particular bajo un universal o la psicología individual en la dinámica social (revelando que el altruismo puede ser agresividad, que una emoción íntima puede ser económica, etc.), el Grungestus combina dos gestus contradictorios: subraya una contradicción o antinomia creando una inesperada identidad de materiales gestuales opuestos. En esta escena, los oficiales orinan en la calle mientras llaman asqueroso al barrio 
y califican a los vecinos de asesinos justo antes de empezar a disparar enloquecidos sin sentido alguno. Nos hallamos, pues, en un escenario donde los «limpios» son quienes orinan por las calles, los agentes del orden son criminales y salvajes y donde, en consecuencia, la justicia se halla, como iremos viendo, completamente perturbada.

Esta inversión de papeles y, en general, de todos los términos recorrerá cada pieza, como un síntoma inherente del predominio de la mentira sobre la verdad. Al igual que en Baal, su obra primeriza, Brecht muestra el crimen como el límite de lo asocial, con una crucial diferencia: ya no se trata del crimen de la sociedad sobre el asocial, «en la época hitleriana el crimen es el del asocial/negativo sobre el resto de la sociedad» (Rodríguez 1998: 112).

\section{VORACIDAD.}

El hombre de la SA de la pieza tercera, «La cruz de tiza», continúa con el mismo tipo de gestos de marcado carácter escatológico, asociados en especial al goce con la comida y la glotonería. Ha ido a visitar a su novia, una muchacha que trabaja en la cocina de una mansión, y acepta quedarse a comer. «Se ha anudado la servilleta al cuello. Levantando tenedor y cuchillo» $^{2}$ (1989b: 6), un gesto habitual, pero que se torna amenazante cuando, a la vez, habla de la habilidad del Führer para dar golpes insospechados, fulminantes, «es eso lo hace que nos teman tanto» (1989b: 6). Tácticas que él mismo se encargará de poner en práctica más adelante.

Si a través del distanciamiento, Brecht dice querer acabar con las falsas dicotomías entre razón y emoción, entre pensamiento y cuerpo, tan enajenante había de ser para él el placer puramente espiritual como el estrictamente corporal. El viejo Galileo (de Galileo Galilę), una vez ha abandonado su labor científica-revolucionaria y didáctica, aparecía comiendo «con una voracidad desmedida, sin preocuparse de nada más; se ha desembarazado de sus tareas educativas como de un fardo» (Brecht 1948). Los intelectuales al servicio del poder son insistentemente retratados en las obras brechtianas como aquellos que no buscan

\footnotetext{
${ }^{2}$ En las citas he respetado la cursiva, que en la obra señalan las acotaciones del dramaturgo, y las mayúsculas, que corresponden al personaje que en cada caso interviene.
} 
con su trabajo «sino el beneplácito de su vientre» (1969: 21).

Algo similar parece suceder con la cerveza y sus efectos, muy presente en Terror $y$ miseria: desde la primera pieza, de cuyos protagonistas ya hablamos ( «Ahí están ya las SS/ la cerveza que no cese./ Van cansados y repletos» [1989b: 2]), pasando por los SA que en «La búsqueda de derecho» destrozan la joyería del judío (declaran que iban «tan solo» buscando tomar un vaso de cerveza), a la última, «El plebiscito», donde un grupo de obreros escuchan la entrada de Hitler a Viena: «No podemos hacer como si no oyéramos esos aullidos de victoria. Señala a la radio. [...] ¿No suenan realmente como un pueblo? LA MUJER. Suenan como veinte borrachos a los que han dado cerveza gratis» (1989b: 84).

De este modo, por medio de las referencias al vientre o la boca llenos, se alude constantemente a la problemática en torno a la relación entre pensamiento, palabra y comportamiento o entre irracionalidad y fuerza bruta, $y$, en definitiva, en torno la posibilidad de decir la verdad. Algo así encontramos en una larga intervención del SA al inicio de «La Cruz de tiza», que se abre con irónicas y amenazantes palabras sobre el secreto y el silencio: « ¡no hay que irse de la boca! », para concluir: «Y yo aquí sentado, con la boca llena de mayonesa- Exagerando, como si tuviera la boca llena:- Heil Hitler! (1989b: 6)». En el sentido opuesto, frente a la glotonería y la embriaguez de los privilegiados y afines al régimen, el juez de la «La búsqueda del derecho» se olvida de comer:

LA CRIADA. Un día se va a olvidar usted la cabeza, señor juez. Es horrible. ¿Qué ha vuelto a olvidarse hoy? Piénselo: ¡lo más importante! [...] Pero no se tome el desayuno demasiado deprisa, que podría hacerle daño. Es tan malo para la salud. [...] La salud es lo más importante (1989b: 32).

Todas estas imágenes alrededor de la comida y la bebida pueden vincularse a la noción brechtiana de «arte culinario»: aquel donde el pensamiento y las consecuencias prácticas se extinguen por completo, que no ofrece más que placeres meramente estéticos, anestesiantes o hipnotizadores para la evasión respecto de la vida cotidiana. En El compromiso en arte y la literatura Brecht observaba que a los fascistas «la arquitectura les es la más querida de las artes. No tiene texto. No tiene texto y sí mucha apariencia. Una piedra perdura siglos» (1973: 1819). El mismo papel de arte carente de palabra parece ocuparlo en muchos momentos de Terrory miseria del Tercer Reich la música: en el gran desfile «No hay gemidos/ ni quejas ni murmullos de viejas. / Música militar» (1989b: 2). La idea de estética que proclama 
el fascismo, como la idea de nación, situaba el arte por encima de intereses políticos y sociales, allí donde la apelación a la pura emocionalidad se impone a la razón y la inteligencia. El vínculo entre el Estado y el arte no es casual, se trata de aquello que Benjamin denominaba, por oposición a la politización del arte, la «estetización de la política» (1996: 23).

Retomando la intervención «con la boca llena» del SA podemos acercamos a otro de los gestos recurrentes en la obra: el saludo que se ha impuesto en la Alemania nazi. Es su ambiguo «Heil Hitler!» lo que delata al obrero (hermano de la cocinera que trabaja con la novia del SA) desde su entrada en escena. El saludo es un gestus por excelencia: logra mostrar cómo lo individual, cotidiano y familiar está intrincado en dinámicas y motivos sociales, es un caso claro de algo hecho costumbre pero que necesita de una explicación más profunda (Jameson 2009: 149). Además, permite vislumbrar las actitudes de cada personaje a través solo de dos palabras, explotando las contradicciones y la no-homogeneidad entre lo que se dice y lo que se hace (Brecht 1969: 40). Así, el «Heil Hitler!» muestra tanto hasta qué punto el régimen nazi ha penetrado en lo más profundo de la sociedad alemana como las disidencias y crímenes escondidos tras la aparente armonía de dicha sociedad unida bajo la bandera.

Si el saludo es un gestus, el final de la intervención del SA, cuando bromea exclamando «Heil Hitler!» con la boca llena, ha de ser un nuevo y grotesco Grundgestus, que parece conectar con lo que sucede al final de la pieza dieciséis, «Socorro de invierno». Allí, una anciana grita el saludo nazi mientras vomita la manzana que le habían dado los mismos SS que ahora se llevan arrestada a su hija embarazada. Frente al dramático final, el inicio de esta pieza parecía, como observa Benjamin, idílico: en este caso son los SS quienes ofrecen alimentos a la anciana y su hija, trayéndolas el socorro de invierno, recompensa al sacrificio del pueblo alemán. Si bien, la siguiente escena revela de manera casi metafórica el trasfondo terrible de la trama: « [la anciana] Muerde una manzana. Todos comen juntos las manzanas, menos la joven» (1989b: 66). La anciana cree formar parte del nuevo proyecto nacional y se muestra agradecida, compartiendo con los SS lo único que tiene. Seducida por su aparente amabilidad, mientras mastica, «parlotea» en exceso sobre las opiniones de la hija y el yerno. «Señala con la manzana a su hija», sin darse cuenta de que es una señal acusatoria: «nada malo, saben, lo que dicen todos. Que los precios han subido un poquito en los últimos tiempos [...]. Y la verdad es que ella ha calculado, con la libreta de la casa» (1989b: 66-67). La libreta (tal vez porque los cálculos no mienten) se convierte así en una huella incriminatoria. Los SS son fulminantes con la chica. 


\section{FARSA.}

El obrero de «La cruz de tiza» es un parado (lo cual le hace aún más sospechoso), pero también es un manitas con la radio que fabrica y monta sus propios aparatos. Si bien su habilidad manual le es inútil cuando el medio de producción está en manos del poder: «Mi hermano entiende mucho de radio. $\mathrm{Y}$, sin embargo, no le interesa nada escucharla. [...]EL OBRERO. A veces oigo música» (1989b: 8). De nuevo, la música remplaza a la palabra cuando esta queda contaminada por la mentira, algo que ha sucedido, antes que en ningún otro ámbito, en la prensa. Lo cual aboca otra vez a un juego de voces y silencios impostados, tal como sucede con el programa radiofónico burdamente manipulado de la pieza trece, o en la décima, «El chivato». Allí, el padre arrebata a su hijo el periódico: «Si todos los diarios publican semejantes porquerías, no leeré ninguno. No estaré menos enterado de lo que pasa en el mundo» (1989b: 49). Obviamente, esto solo puede decirlo en un descuido del que acabará arrepintiéndose, porque quien, como el vecino de «La delación», es pillado buscando algo de verdad en emisiones extranjeras acaba golpeado y detenido.

El SA de «La Cruz de tiza» también ha comenzado a tramar su golpe y detención del obrero desde su sospechoso saludo: «Nunca sospecho nada. Sabe, eso es ya casi una certeza. Y entonces la cosa va en serio. [...] Echado hacia atrás y con un ojo cerrado: ¿Entendió usted lo que murmuraba? Imita el saludo del obrero» (1989b: 8). De esta manera, al ser repetido por otro personaje, el gesto vuelve a sernos distanciado. Vamos descubriendo que el «Heil Hitler!» es mucho más que una mera forma de saludo y que podía ser dicho de muchas maneras.

Luego le invita a sentarse y confirmamos que sus gestos ante el plato no eran tan inocentes: «EL HOMBRE DE LA SA, al obrero: ¿Por qué no se sienta? No nos comemos a nadie». El SA comienza así con sus artimañas. Primero hace un truco con la cerveza: finge enfadarse porque alguien se la ha bebido. «Riéndose a carcajadas. Bueno, calmaos. ¡Es un truco de nuestra cantina! Tomarse la cerveza sin que nadie se dé cuenta» (1989b: 9). Brecht viene a presentarnos algo así como un gesto invisibilizado: el acto de beber la cerveza ha sido borrado. En eso consiste, al fin y al cabo, todo «truco»: en ocultar lo que ocurre en verdad, 
dándole un aire fantástico o incomprensible. El SA ha actuado tal como antes decía que hace el «Führer cuando está preparando un golpe! ¡Impenetrable! No se sabe nada de antemano. Quizá ni él mismo lo sabe de antemano. Y luego, como un relámpago. Las cosas más increíbles» (1989b: 6).

Como el obrero no parece sorprendido le invita a imitarlo: «EL OBRERO. Bueno. Aquí tengo la cerveza -levanta el vaso-, y ahora viene el truco. Se bebe la cerveza tranquilamente y con placens (1989b: 9). Con este gesto algo satírico parece haber desactivado el misterio, sacando a la superficie y simplificando la acción. Tal vez pueda verse algo de la astucia brechtiana en la maniobra del obrero: ese pragmatismo o actitud particular que como decía Jameson: «transforma el problema en su solución [...], entra lateralmente en el asunto y lanza el proyectil en una dirección nueva y más productiva que el callejón sin salida donde hasta ahora estaba paralizado» (2009: 44).

De este modo se inicia una especie de lucha soterrada. Se trata, como en Los Horacios y los Curacios, aunque en el terreno de la palabra, de un despliegue por ambas partes (cuya fuerza, si bien, es desigual) de tácticas y herramientas. Ya sabemos cuáles son las del SA: «Coger al enemigo por sorpresa!», también quiénes son sus presas: «Vivir y dejar vivir. Y de vez en cuando alguna broma. ¿Por qué no? Sólo somos duros en lo que se refiere a la forma de pensar» (1989b: 10). El problema es que el terror hace que la gente haya aprendido a callarse lo que piensa. Así pues, el SA se dispone a enseñarles cómo consigue que sus enemigos acaben delatándose. Para ello va a iniciar una especie de pequeño teatro, pidiéndole al obrero que le ayude: van a fingir que se hallan en la cola de la oficina de subsidio. «No es más que teatro, Franz. Sabemos que lo que digas no será lo que realmente piensas. [...] Por decirlo así, interpretas el papel de un protestón» (1989b: 11) («protestón» es otra de las palabras que se repiten a lo largo de la obra, aplicada a quienes señalan que las cosas no están tan bien como se pretende). A partir de este momento todo sucede como si perteneciera al ámbito de la broma o el juego, pero al mismo tiempo sabemos que la misma farsa es una farsa (que el obrero es realmente un protestón de los que no dicen Heil Hitler! como es debido y que el SA le está tendiendo una de sus trampas). Los fines de la actuación no son recreativos, se trata más bien de una especie de experimento (así lo denomina el SA) que recuerda al realizado por Hamlet para delatar al criminal (aunque tal como veremos al hablar de la justicia, aquí todo esté dado la vuelta de manera perversa). De este modo (porque los personajes no hablan en su nombre) la escena está marcada por un claro efecto distanciador, 
consiguiendo que las palabras y frases habituales tomen un cariz totalmente diferente y que, como entendía Brecht que debía hacer el arte teatral, se digan cosas que nunca se dirían en otras manifestaciones públicas (2004: 37).

En la pieza dedicada a la mujer judía que se dispone a huir a Ámsterdam encontramos algo parecido. Ella también monta su propio teatrillo y experimenta con diversas maneras de explicarle a su marido que se va. Pero solo hablando con la silla vacía se atreve la mujer a decir ciertas verdades. Estas escenas nos muestran, no solo que el actuar es una dimensión ineludible de la vida social y cotidiana (Jameson 2009) sino que, al menos en este contexto, perseguidos y perseguidores han de fingir constantemente y pronunciar frases estereotipadas o consignas que el régimen propaga y usa para educar a los jóvenes. Asimismo, en la pieza trece, «La hora del obrero», una obrera repite ante el locutor las frases que, obviamente, le han hecho aprenderse de memoria sobre supuestas mejoras en la fábrica, pero sus respuestas «automáticas» resultan totalmente incoherentes respecto a las preguntas de aquel. Como decíamos, el cometido del teatro brechtiano (a través del efecto distanciador y del gestus) es sacar a la luz toda esa retoricidad reprimida de las expresiones cotidianas (Eagleton 2007). Si el comportamiento y, con él, el pensamiento mismo, son algo aprendido socialmente, las personas fácilmente acaban adoptando todas estas consignas y actitudes como propias

El obrero, que desconfía del SA tanto como el SA de él, comienza su actuación de manera poco realista: con un insulto directo, proclamándose judío y marxista. "¿No tiene dos dedos de imaginación? Tiene que decir algo a lo que, llegado el caso, pudiera dar otro sentido, algo que realmente pueda decirse». El SA hace de sí mismo: «Entonces yo seguiría otro método y diría: pero lo que ellos tienen grande es la bocaza» (1989b: 11). Cuando se trata de hacer hablar a su presa, también ellos tienen que actuar y fingir, a veces incluso diciendo la verdad.

El obrero continúa con el juego: «A pesar del chiste, usted podría ser un soplón» (1989b: 12) (algo que nunca le hubiera respondido a las anteriores bromas, antes de empezar el experimento). El obrero nunca desafía directamente al SA. Desde luego, no es un héroe, al menos no al modo trágico. La heroicidad y la valentía no son valores en sí mismos, hay que tener las armas necesarias para jugarlos sin que nos conduzcan a una acción suicida de la que el enemigo saldrá indemne. En ocasiones son más bien privilegios para unos pocos: «cuando se tiene el tejado de vidrio hay que ser prudente. Yo soy cobarde y no tengo 
revólven». Pero cuando la prudencia se vuelve criterio de toda acción, la voluntad termina por convertirse en una palabra vacía: «Bonita voluntariedad, ¿نverdad? El Servicio Voluntario de Trabajo es uno de los temas favoritos» (1989b: 12). Y es que el terror puede más que los golpes directos: «ya nadie se atreve a resistirse. Nos pueden dar mierda de comer y todavía les daremos las gracias» (1989b: 13).

\section{SUPERVIVENCIA.}

A continuación, el obrero, siguiendo con su papel, cuenta un par de anécdotas propias de un buen protestón. Nuevamente se trata de una escena marcadamente brechtiana, que a través de la narratividad y del citar lo que otros dijeron consigue crear un efecto de distanciamiento. Además, ambas tienen una forma que las aproxima a la fábula o la parábola ${ }^{3}$.

En la segunda anécdota ${ }^{4}$ el obrero cuenta su hipotético encuentro con una anciana en Alexanderplatr, que al final se descubre como otra peligrosa protestona. Su relato habla en el fondo (como toda la obra) de la situación de miseria que sufre gran parte de la sociedad alemana y de la enorme contradicción existente en ella entre toda esa pobreza, hambre e irracionalidad en el plano social frente al increíble desarrollo de la técnica y la razón científica. En palabras de la mujer judía: «Inventáis la teoría de los cuantos y la cirugía del pulmón y os dejáis mandar por semisalvajes que os ofrecen conquistar el mundo pero no os dejan tener la mujer que queréis tener» (1989b: 45). Pero el principal objetivo de la ciencia era la guerra, al tratarse de la supervivencia de la nación quedaba justificada la prevalencia de la tecnología armamentística sobre la miseria: «Alemania, y eso es a prueba de bomba, necesita cañones y no manteca» (1989b: 69). Ahora bien, la cuestión no es que el triunfo nazi sea el culpable de los problemas económicos de los de abajo. Al contrario, Brecht tenía claro que eran las contradicciones y la crisis del sistema capitalista lo que había llevado al triunfo del fascismo:

\footnotetext{
${ }^{3}$ El empleo de la parábola también es propio de la escritura de Brecht, vinculada a su vocación didáctica. Como explica Jameson, la parábola se basa en el juego de contraposiciones o de dobles discursos : el material narrativo se divide en dos: la anécdota (donde el personaje aparece haciendo algo con ciertos resultados) y, en un orden más abstracto (que se yuxtapone a la narrativa precedente), una lección o moraleja (2009: 175)

${ }^{4}$ Omitimos aquí el primero de los relatos que cuenta el obrero por razones de espacio y, tal vez, también de pudor. Pues con él Brecht lleva mucho más allá los elementos escatológicos. Sí podemos enunciar la conclusión o la lección básica que parece proponer: cuando uno está sometido a la violencia, es capaz de admitir e incluso de sentir agrado hacia cosas que en circunstancias normales jamás admitiría o le repugnarían.
} 
el salvajismo del fascismo «no viene del salvajismo, sino de los negocios, que sin él no podrían seguir haciéndose» (1973: 175). Solo la guerra hacía posible la movilización de los medios técnicos existentes conservando las relaciones de propiedad. Se pasó entonces, como decía Benjamin, de la praxis de la producción a la praxis de la destrucción: «En lugar de canalizar ríos, dirige la corriente humana al lecho de sus trincheras; en lugar de esparcir grano desde sus aeroplanos, esparce bombas incendiarias sobre las ciudades» (2008: 83).

Volvemos así a encontrar toda una serie de imágenes y alusiones en torno a la comida. Pero su sentido es opuesto, contradictorio, con respecto a los casos de los que hablamos anteriormente. $\mathrm{Y}$ es que el asunto es muy diferente según la situación social de cada cual: «Para los de arriba hablar de comida es bajo. /Y se comprende porque/ ya han comido. / Los de abajo tienen que irse del mundo / sin saber lo que es / comer buena carne» (1989).

Como hemos visto, el fascismo puso en marcha una propaganda radiofónica y educativa que pedía a la población desprendimiento en favor del fin supremo del pueblo y la nación: ya que «no proporciona comida, debe educar para la disciplina [...]. Como necesita victimas, ha de inculcar en las gentes el espíritu de sacrificio » (Brecht 1973). Pero el sacrificio es solo para algunos: cuando la mujer de Alexanderplatz va a ofrecer al Socorro de invierno un sofá, se lo rechazan porque prefieren los pianos. Por su parte, el SA, que «no se hace de rogar» cuando su novia le pide que se quede a comer, se muestra firme cuando ella le dice que necesita dinero de la cartilla que comparten para arreglar su reloj o comprar un abrigo a su hermana: no quiere que le «saquen los cuartos». Mientras, él exhibe unas botas nuevas y caras: «sin dejar de masticar, estira una pierna para que le vean la bota», en un gesto claramente opuesto al de la niña de la pieza «Los zapatos negros» que ha de elegir entre sus viejos zapatos agujereados y los feos y excesivamente grandes de la beneficencia. Si bien, más adelante descubrimos que al SA le ha tocado pagar sus botas, cuando creyó que el servicio corría con los gastos. Tal vez él también sea un títere en manos de otros.

A la abstracción de las ideas de «pueblo»y «nación» se opone la verdad de lo concreto, de las auténticas necesidades materiales para vivir, como bien expresa «El campesino que da de comer a la cerda»: «Tengo que entregar mi trigo por nada, pero tengo que comprar cara la comida del ganado. Para que ese señor pueda comprar cañones». Y concluye «Cuando un animal tiene hambre, el Estado no es nada» (1989b: 69). Por eso no hay que dejarse cautivar, la victoria en la guerra conduce igualmente a la población a la 
catástrofe y la muerte: «Buena mujer, tenga cuidado con lo que me dice, porque yo soy nacional hasta los huesos. Huesos, dice ella, pero nada de carne, y salvado en el pan» (1989b: 13). Un final no muy distinto del que les espera a los obreros del campo de trabajo en la pieza cuarta. Estos cavan con sus picos hacia el pantano, mientras el SA de turno les ordena que se callen: prefiere que canten (de nuevo se imponen la música y los cantos para la Nación): «Pero no nos quejaremos/ el invierno acabará /y algún día exclamaremos/ ipatria, eres mía ya!» (1989b: 21). Donde en realidad acaban es en la casamata, ahora acusados de lo contrario: de permanecer callados y no acusarse entre sí: «¿Quién ha gritado «traidores del pueblo»?Nadie responde» (1989b: 22).

Su canción no sería sino una variante de esas baladas patrióticas que, como dice Benjamin, acompañan a los soldados al matadero: «Los de arriba dicen: /Hacia la gloria. /Los de abajo dicen: /Hacia la tumba» (1996: 36). También se podrían retomar aquí las palabras del poema Contra la seducción, donde Brecht se refiere a los sermones religiosos y su apología del sacrificio ante la esperanza de una segunda vida. A estas alturas las promesas del movimiento nazi parecen haber sustituido con creces a los de la Iglesia: " ¡No creáis en promesas! /Vuestro tiempo no dura! [...] ¿Para qué tanto ayuno?... Bebedla en grandes tragos! /No os habréis saciado /Cuando haya que partir! »(1998). Queda claro, como ya ocurría con el gesto de nuestro obrero bebiéndose la cerveza sin artificios, que pese al empleo negativo de las imágenes de la voracidad y la bebida, Brecht no es un ningún defensor del ascetismo:

Dicen que el canciller no bebe /que no come carne ni fuma [...]. / Pero también dicen que los pobres / pasan hambre y languidecen en la miseria. Cuánto mejor sería un Estado del cual se dijera; /El canciller preside borracho la reunión de gabinete; /contemplando el humo de sus pipas, algunos ignorantes / reforman las leyes. /Pobres no hay (Brecht 1969: 70).

El problema es que aunque uno no se deje seducir cualquier forma de oposición directa parece inconcebible. Para seguir viviendo se está obligado a callar y aceptar lo que ocurre. Así se exculpaba el hombre de la pieza veintitrés, «Contratación de mano de obra», cuando la vecina le advierte que en su trabajo construye motores para la guerra: « ¡no hay nada ya que no sea para la guerra! ¿Dónde voy a encontrar trabajo si me digo: ¡pero que no sea para la guerra!? ¿'Tendré que morirme de hambre?» (1989b: 14). 
La guerra borra todos los límites: entre lo civil y lo militar, entre la ciencia y la técnica, entre la patria y el pueblo, para reducirlos al límite único de la supervivencia (Rodríguez 1998: 44), tras cuyos alambres no hay nada. Ya lo cantaban los obreros del pantano: «y nadie podrá escapar. /No hay huida si no vuelas. / Cuatro muros que saltar» (1989b: 21). En un gesto irónico Brecht apunta que incluso más allá de la muerte uno ha de seguir callando: «¿Allí arriba se podrá abrir la boca, no?» (1989b: 73) dice el moribundo de «El sermón de la montaña». De esta manera, el nazismo se presentaba verdaderamente como una catástrofe imparable: «Todo parece otra vez una infección... Es realmente una desgracia» (1989b: 46), se lamenta el marido de la mujer judía; o según los obreros de «El plebiscito»: «Es como un mar [...], no hace más que vencer y vencer» (1989b: 83).

\section{Huellas.}

La escena crucial de «La cruz de tiza» se produce cuando, al terminar la pequeña dramatización, el SA realiza su truco final: podría conseguir, afirma, que detuvieran al obrero sin necesidad de seguirle ni de hacer señas. Casi como un mago, le invita a que se mire la espalda. Ha conseguido pintarle una cruz de tiza en la chaqueta sin que, de nuevo, nadie se percate. Brecht muestra así que cualquiera, incluso el más prudente, está en riesgo de acabar en el Servicio Voluntario o en el campo de trabajo. Todo puede convertirse en motivo de sospecha y de acusación: «Será mejor que no parezca tan inocente. Eso llama la atención» (1989b: 19).

Pero con su pequeña farsa el hombre de la SA ha descubierto su verdadera cara: «LA MUCHACHA. Ha cambiado tanto. Lo han estropeado por completo. [...] ¡Por favor, mire si no tengo yo también una cruz en la espalda!» (1989b: 19). Las personas cambian cuando cambian las circunstancias. «El carácter es una cuestión de tiempo. Sólo dura cierto tiempo, como los guantes» (1989b: 44), señala la mujer judía, pensando en cómo se ha transformado el modo en que la trata su marido. $\mathrm{Y}$ de igual manera puede cambiar el lugar social en que uno está. Si bajo el capitalismo «un hombre es su valor en el mercado» y el fascismo es en el fondo un capitalismo llevado a sus límites en un intento desesperado por salvarse, entonces, «bajo el nazismo ningún hombre vale nada» (Rodríguez 1998: 66). Se trata 
nuevamente de una inversión perversa del verdadero orden de las cosas, de un intercambio desigual de los papeles, que revela si bien la perversidad del sistema para quienes antes no querían ver:

En los últimos tiempos he pensado a menudo que hace años me dijiste que había personas que valían y otras que valían menos. [...] iY yo estaba de acuerdo, estúpida! Ahora han hecho una clasificación de ésas, y resulta que pertenezco a las que no valen nada (1989b: 44).

" iTiene una cru₹, una cruz blanca!», se sorprendía la muchacha. Vale la pena detenerse en este momento porque la imagen de la tiza es clave en la dramaturgia brechtiana. En ella, como apunta Rodríguez, habría encontrado la raíz de su idea de teatro épico (1998: 129). Aparece también en sus poemas: «En el muro estaba escrito con tiza: 'Ellos quieren la guerra’. /El que lo escribió / Ya está muerto» (1989). Aquí, según Benjamin, el gesto de la inscripción efímera y apresurada en tiza se contrapone a los grabados en piedra «lapidarios» y a lo que deberían ser palabras que, por su forma poética, sobrevivieran a «la próxima catástrofe universal» (1996: 56).

En el caso de la cruz de tiza es posible ver igualmente una forma de señalar la condena de nuestro obrero, y, al fin, de los perseguidos, de los sin-nombre, pues se trata de una huella que permite dar con el «criminal». Ya en El Libro de lectura para los habitantes de la ciudad exhortaba Brecht a borrar las huellas a quien se mueve en la ilegalidad en su lucha por la clase explotada: «Si encuentras tu pensamiento en otro; niégalo. [...] Que ninguna piedra delate el lugar donde yaces». Exhortación que como nos enseña Benjamin ha de complementarse con la del noveno poema: «mejor que si te las borran» (1996: 51). Mientras, las huellas de los verdaderos delincuentes se borran con facilidad o resultan imposibles de seguir. Por eso al juez de «La búsqueda del derecho», aunque quisiera, le será imposible emitir un buen juicio. El «escrito de acusación [...] flojo y chapucero» le hace imposible dar con el «trasfondo del caso» (1989b: 25). La realidad y la verdad parecen disolverse entre testimonios e intereses diversos. También en esta sexta pieza todos los papeles se invierten y, al igual que las huellas del crimen parecían revertir su sentido y llevar desde los delincuentes a las víctimas, es el juez el que parece ir a ser juzgado. Al final, el ujier le informa de que ha logrado poner orden entre la gran cantidad de gente que pretendía entrar en la sala: «el señor Fiscal General se negó a sentarse con los testigos. Quería sentarse en la mesa del tribunal. ¡Y entonces usted 
hubiera tenido que dirigir el juicio desde el banquillo de los acusados, señor juez!» (1989b: 36). La escena no ahonda sino en aquello que Brecht encontraba más interesante en la obra de Kafka: su capacidad para explorar qué ocurre con el hombre que debe atenerse a la ley pero no tiene ley a la que atenerse (Rodríguez 1998).

\section{Egoísmo.}

El obrero de «La cruz de tiza» concluye su paso por escena con un satírico discurso sobre lo que es ser (o comportarse como) alguien que «piensa bien» bajo Tercer Reich: «Si alguien me confía algo, va listo. [...] si nos ponemos en contra de nuestra propia carne y nuestra propia sangre, el Tercer Reich, al que amamos por encima de todo, no perdurará. ¿Lo he hecho mejor ahora? ¿Está contento conmigo?» (1989b: 14). De este modo retrata el fondo común a los diversos escenarios que presenta la obra: la desconfianza, crueldad y degradación de las relaciones engendradas por un orden basado en el terror y la miseria. Llegamos así a una de las claves de la visión brechtiana sobre los males de la sociedad moderna capitalista y que el fascismo llevaría al límite: el tema que Rodríguez llama «del significado auténtico de la Bondad/Maldad».

Cuando uno se somete al bien del ideal de la nación, desatiende a sus iguales de carne y hueso; cuando todas esas personas ya no valen nada, cada uno solo puede mirar por sí mismo, «volviéndose malo». El resultado es la corrosión, la depravación y la desconfianza cada vez más profundas de las relaciones sociales, hasta en su núcleo más íntimo. Así, la muchacha que en principio parece enamorada del SA al final solo puede sentir miedo por él. El comportamiento del padre de «El chivato» a lo largo de la escena demuestra que cuando afirmaba «entre estas cuatro paredes puedo decir lo que me parezca» (1989b: 48) se estaba engañando: el miedo a que su hijo pueda denunciarle por su comentario sobre la prensa va in crescendo hasta que al final le encontramos aterrado, junto a su mujer, cuando se abre la puerta de la casa, convencido de que vienen a detenerle. Aunque solo es el chico, que vuelve de comprar unos bombones, la sospecha permanece aún en la última frase: «¿Crees que dice la verdad?» (1989b: 55). La mujer judía, a pesar de que incluso su marido empieza a contaminarse de la hostilidad que hacia ella muestran ya casi todos sus conocidos, declara 
que: «si me voy es puro egoísmo por mi parte, nada más» (1989b: 44). En «La búsqueda de derecho», el auténtico trasfondo del caso sobre el que el informe no daba pistas nos lo revela el inspector: «Señor juez, tengo familia». En efecto, el juez acaba convirtiendo ese mismo temor personal en el criterio de su sentencia: «itienen que decirme qué resolución convendría a los intereses superiores!» (1989b: 25).

Todo ello apunta al error de quienes creen que contra el estado salvaje basta con llamar a la implantación de la bondad (Brecht 1973: 174). Como de costumbre, Brecht dará una vuelta iluminadora a las concepciones usuales: no se trata de reprobar el egoísmo, la maldad o el autointerés, tomándolas como meras conductas particulares. Eso es justamente lo que hacían las prédicas fascistas a favor de la unidad nacional y el sacrificio (y en general, todas las que lanzan los explotadores hacia los explotados): el viejo combatiente Lettner, de la pieza diecinueve, «siempre hablaba de la Causa y en contra del egoísmo del individuo» (1989b: 71). Para el autor «la fuente de toda moralidad y toda inmoralidad» reside en el «orden social existente y sus condiciones de producción» (Brecht 1969: 56). Tal como sentencia Meti, allí donde existen grandes diferencias de ingresos la bondad es dañosa: «bajo el capitalismo uno solo puede amar al prójimo cuando no se ama a sí mismo» (1969: 55), algo que encarna perfectamente la muchacha sumisa de «La cruz de tiza» que se desvive por el SA.

El problema está, pues, en un orden social donde la acción desinteresada se ha convertido en un acto de autodestrucción y hacer el bien para uno mismo en algo perjudicial para los otros, de modo que las masas se ven obligadas por fuerza a descuidar sus propios intereses (Brecht 1969: 22), y es de esa descomposición de los vínculos entre las personas de donde los poderosos sacan su mayor fuerza.

\section{DECISIÓN.}

Volvemos a toparnos así con el problema de la imposibilidad de salirse del límite, aun ante la catástrofe imparable. Pero la solución no está en el egoísmo ni en continuar con el silencio. Como termina exclamando la mujer de «Contratación de mano de obra la vecina» la distancia entre callar «como un muerto» y estar muerto no es tanta: 
¿Vamos a tener que callar para que no te quiten el puesto? ¿Por qué moriremos si no fabricamos sus bombarderos? ¿Y para morirnos luego de todos modos? ¿Cómo Franz? A él también le han buscado un puesto. A un metro bajo tierra. [...] EL HOMBRE. Quiere cerrarle la boca: ¡Cállate! ¡Eso no sirve de nada! LA MUJER. ¿Qué sirve entonces? ¡Haz algo que sirva! (1989b: 23)

La única respuesta posible es «hacer algo» y algo que «sirva», que sea útil y que, por tanto, implique intervención y praxis. La mujer de Alexanderplatz representa esta decisión límite: «buena mujer, ¿para qué quiere cañones? ¿Con la tripa vacía? No, dice ella, si tengo que morirme de hambre, más vale arrasar por completo a toda esa chusma, con Hitler a la cabeza» (1989b: 14). Es la misma resolución a la que llegaba la protagonista de Los fusiles de la Señora Carrar, una «pequeña pieza dramática» con la que Brecht decía haber intentado mostrar cuán difícil le resulta a una pescadora tomar la decisión de empeñarse en la lucha contra los generales, «como no empuña las armas más que en extrema necesidad. Porque la humanidad tiene que hacerse guerrera en los tiempos que corremos para no ser exterminada» (1973: 170).

La respuesta está, sí, en la bondad, pero una clase de bondad no compasiva, que «también hiere. Hiere al salvajismo», en una moralidad que ha de exudarse «por todos los poros», pero para dirigirla a la lucha contra los opresores; está también en la inteligencia, pero nuevamente, en una inteligencia «fuerte, temible, devoradora» (Brecht 1973: 179).

El mismo Brecht, que había descrito la historia del siglo XX como un diluvio universal (Rodríguez 1998: 67), hace decir al padre de «El chivato» que «es una calamidad que hoy llueva» (1989b: 48) pero solo para aclarar a continuación: «no se puede vivir en un país en que es una calamidad que llueva». Hay que llamar a las cosas por su nombre, no tomar las condiciones dadas como naturales o eternas y comprender sus causas profundas, por mucho que el nazismo se presentara como una fuerza imparable e impenetrable. Tal es el consejo del médico en la pieza «La enfermedad profesional»: «sin preguntas e investigaciones siempre renovadas sobre las causas profundas de la enfermedad, la medicina se convierte en puro curanderismo». Nada de trucos por tanto, las tres cosas que debe saber un buen médico son: «preguntar, preguntar y preguntar. Y preguntar sobre las cuestiones sociales» (1989b: $37)$.

Solo cuando se duda de todo lo que se nos dice y de lo que nosotros mismos 
decimos, de aquello que se nos ha vuelto costumbre ${ }^{5}$, cuando se pierde el miedo a la verdad y a los riesgos que conlleva, uno puede soportar vivir sin esperanza porque «sabe cómo llegó a ese punto» (Benjamin 1996: 22). Y es que solo conociendo la situación en que se encuentra podrá sacar el mejor partido para comenzar a cambiarla: uno únicamente «puede detener el golpe, si sabe cuándo cae y hacia dónde y por qué, y para qué cae» (Brecht 1973: 173). De este modo, lo inestable y cambiante de las cosas puede llevar a que finalmente lo más insignificante y sencillo termine por vencer: «Que el agua blanda en movimiento /Con el tiempo vence a la piedra poderosa» (Brecht, 1873b: 104). Contra el terror y la miseria es necesario el compromiso, un compromiso ante todo con la verdad. Entendiendo que, para Brecht, la verdad es siempre una cuestión concreta y sujeta a la práctica, algo nunca dado, que ha de ser propagado, para lo cual se requiere «del arte de hacerla manejable como un arma» (1973). Y como un arma de lucha y resistencia en favor de la verdad y de la construcción de un mundo más amable escribió Brecht obras como Terror y miseria del Tercer Reich.

\section{FINAL DE VIAJE.}

Con todo lo dicho resulta obvio que las advertencias sobre que la vida es breve y a no dejarse despojar de la más mínima porción de ella no son llamadas a salvarse a sí mismo. Si el obrero de «La cruz de tiza» parece irremediablemente condenado a la derrota se debe, en buena medida, a que está solo. La clave podemos hallarla resumida en forma de parábola en la interpretación que Brecht daba a La aldea más cercana de Kafka:

Una contrapartida de la historia de Aquiles y la tortuga. Uno no llega nunca a la próxima aldea si compone el viaje con la suma de sus partes más pequeñas- sin contar los accidentes. Entonces la vida es demasiado corta para ese viaje. Pero la falla está aquí en ese 'uno'. Pues si el viaje se divide en partes, lo mismo le sucede al viajero. Y si desaparece la unidad de la vida, también desaparece su brevedad. Puede ser tan breve como se quiera. Eso no importa, pues el que llega a la aldea es otro que el que emprendió el viaje (Benjamin 1996: 67).

\footnotetext{
${ }^{5}$ Brecht elogiaba a la duda como principio del conocimiento. Pero como decía por boca de Me-ti esta ha de tener un límite: la acción. « ¡De qué le sirve poder dudar al que / no se puede decidir! » (1969: 80).
} 
Y esta idea del viaje nos lleva de retorno a la cuestión del exilio brechtiano y su pretensión de mantener la lucha aun desde la distancia. En uno de sus poemas advertía: «Cada uno/ de los que vamos con los zapatos rotos entre la multitud/ [...] ninguno de nosotros/se quedará aquí. La última palabra aún no ha sido dicha» (Brecht 1989). Esa última palabra, encargada de mostrar que la historia sigue abierta, tal vez sea la que cierra la última de las piezas de Terrory miseria. En ella el grupo de obreros, que dudan si arriesgarse a distribuir una octavilla ante el (supuesto) plebiscito de 1938, leen en voz alta la siguiente carta aprovechando el ruido del desfile radiado: «Nuestra tarea es muy dura, pero es la más grande que existe, librar a la humanidad de sus opresores. [...]Tú eres todavía muy joven, pero hace falta que sepas cuál es tu lado. Sé fiel a tu clase, y tu padre no habrá padecido en vano su duro destino». Palabras que lograrán que se sobrepongan al miedo de ser descubiertos: « ¿Qué debe decir entonces la octavilla para el plebiscito? LA MUJER, pensando: Lo mejor será una palabra sólo: ¡NO!» (1989b: 84-85).

De igual modo que pedía una moral que hiriera al salvajismo, Brecht se desvivió por conseguir también lo mismo con su literatura: «¿Cómo podemos los escritores escribir mortalmente?» (Brecht 1973: 179). Como decía Benjamin analizando El libro de lectura para habitantes de la ciudad «el que lucha por la clase explotada es, en su propio país, un exiliado» (1996: 51). Y así, Brecht, que se sintió siempre, en cada sitio, como un huésped y un extraño (Rodríguez 1998) se empeñó (convencido de que el mundo es transformable) en hacer un teatro que ayudara a transformar el mundo ( $\mathrm{y}$ a transformarnos) con el fin de hacerlo más habitable. Aunque fuera solo para las generaciones del futuro. Sin importar que en la victoria su nombre se borrara como la tiza:

Pero hoy / estoy de acuerdo con que se olvide. / ¿Por qué /hay que preguntar por el panadero cuando hay bastante/ ¿Por qué / hay que alabar a la nieve que se ha fundido / cuando se preparan nuevas nevadas? / ¿Por qué / ha de haber un pasado, si hay / un futuro? / ¿Por qué / ha de citarse mi nombre? (Brecht 1873b: 124). 


\section{BIBLIOGRAFÍA}

Benjamin, Walter (1996): Brecht: Ensayos y conversaciones, Montevideo, Arca editorial.

Benjamin, Walter (2008): «La obra de arte en su época de reproductibilidad técnica», en Obras Completas I.2, Madrid, Abada.

Brecht, Bertolt (1967): Pequeño Organon para teatro. En: https://es.scribd.com/doc/24993807/Brecht-Bertolt-Pequeno-organon-para-el-teatrocompleto-1948 (último acceso: 11/11/2018).

Brecht, Bertolt (1973): El compromiso en el arte y la literatura, Barcelona, Península.

Brecht, Bertolt, (1973b): Poesías (traducción de J.M. Valverde). En: https://archive.org/stream/PoesiasBrechtPorValverde/PoesiasBrechtporValverde_djvu.tx t (último acceso: $11 / 11 / 2018)$.

Brecht, Bertolt (1969): Me-ti. El libro de las mutaciones, Nueva visión, Buenos Aires.

Brecht, Bertolt (1989): Poemas y canciones, Madrid: Alianza Editorial, En: https://sites.google.com/site/bertoltbrechtpoemasycanciones/(último acceso: 11/11/2018).

Brecht, Bertolt (1989b): Terror y miseria del tercer Reich. Madrid: Alianza. En: http://www.elsarbresdefahrenheit.net/documentos/obras/2333/ficheros/Brecht_Bertolt_ Terror_Y_Miseria_Del_Tercer_Reich.pdf (último acceso: 11/11/2018).

Brecht, Bertolt (2004): Escritos sobre teatro, Caracas, Alba editorial.

Eagleton, Terry (2007): «Brecht y la retórica». En: http://www.circulobellasartes.com/revistaminerva/articulo.php?id=189 (último acceso: $11 / 11 / 2018)$.

Jameson, Frederic (2009): Brecht y el Método, Buenos Aires, Manantial.

Ray, Gene (2012): «Radical Learning and Dialectical Realism: Brecht and Adorno on Representing Capitalism». En: https://chtodelat.org/b8-newspapers/12-38/gene-rayradical-learning-and-dialectical-realism-brecht-and-adorno-on-representing-capitalism (último acceso: 11/11/2018).

Rodríguez, Juan Carlos (coord.) (1998): Brecht: siglo XX. Granada, De guante blanco. 
SOBRE LA AUTORA

\section{Alba Baro Vaquero}

Alba Baro Vaquero es graduada en Filosofía por la Universidad de Valladolid. Estudió el Máster en Estudios Avanzados en Filosofía impartido por la misma Universidad, así como el Máster en Filosofía de la Historia de la Universidad Autónoma de Madrid. Actualmente es estudiante de doctorado en Filosofía y Ciencias del Lenguaje también en la Universidad Autónoma de Madrid.

Contact information: Correo electrónico: alba.barovaquero@gmail.com 